\title{
Perlindungan HAM dalam Masyarakat Bernegara
}

\author{
Sri Hastuti Puspitasari
}

\begin{abstract}
As its characteristics of legal nation (the rule of law), human rights protection for societies is obligatory for a nation. Government as the holder of political authority on the basis of legal agreement and legitimacy can enforce an intervention, in the form of: firstly: keeping a functional relation between nation and its citizens; secondly, actively involving in avoiding social conflict vertically or horizontally. Institutionalizing the human rights protection towards the state policy is intended to widen its essential values and meaning of which it is a fundamental human right.
\end{abstract}

\section{Pendahuluan}

Dalam dinamika kehidupan bernegara, ada tiga hal yang tidak bisa dilepaskan dari konteks pembicaraan. Pertama, masyarakat yang menjadi elemen utama negara. Kedua, negara yang menjadi institusi organisasi kekuasaan dan merupakan wadah ekspresi masyarakat dalam mengartikulasi berbagai kepentingannya. Ketiga adalah ekses yang muncul dari relasi masyarakat dan negara, dan ekses ini berwujud pada masalah hak-

hak asasi dari individu-individu yang menjadi bagian dari masyarakat dan negara.

Masyarakat adalah suatu perpaduan dan kesinambungan yang nyata, yang dijaga kesatuannya melalui suatu konsensus yang luas, di antara para individu dan kelompokkelompok yang mendirikannya. ${ }^{1}$ Masyarakat merupakan sebuah komunitas yang mengalami perkembangan dari bentuk yang sederhana ke bentuk yang kompleks. Dalam

'Achmad Ali. 1978. Menjelajah Kajian Empiris Terhadap Hukum. Jakarta: Yarsif Watampone. HIm. 147. 
pandangan Durkheim, masyarakat yang sederhana memiliki solidaritas mekanis-yaitu solidaritas berdasar keserupaan, kesamaan, konsensus dan dapat dipertukarkan antara individu dalam masyarakat tersebut - dan pada masyarakat yang kompleks diikat oleh solidaritas organis-yaitu solidaritas yang didasarkan atas spesialisasi, perbedaanperbedaan dan mempunyai sifat saling ketergantungan. Dalam relasi antar individu ditengah masyarakat ada situasi anomie yaitu di mana individu-individu tidak cukup terintegrasi dan tidak cukup didisiplinkan. ${ }^{2}$ Jika berpijak pada pandangan Durkheim, maka kemungkinan masalah HAM: muncul seiring dengan perkembangan masyarakat tersebut di mana di dalamnya selalu ada friksifriksi akibat terjadinya konflik yang dipicu oleh benturan berbagai kepentingan, apakah itu kepentingan individu, kelompok maupun kepentingan yang mengatasnamakan negara. Di dalam masyarakat yang sederhana, kuantitas persoalan HAM yang dipicu oleh konflik antara individu dan kelompok lebih banyak daripada yang dipicu oleh kepentingan yang mengatasnamakan negara. Hal ini disebabkan oleh karena masyarakat sederhana belum terikat dengan aturan-aturan formal yang dibuat oleh institusi legislatif sebagaimana yang ada di negara modern. Dalam pandangan Roberto Mangaberio, masyarakat yang sederhana (tradisional) sedikitnya mempunyai 3 (tiga) elemen kesadaran. Pertama, adanya aturan-aturan alamiah yang senantiasa dipelajari dan dipelihara. Aturan-aturan ini mengikat perasaan masyarakat. Kedua, kepentingan individu dan kelompok adalah hal yang utama. Ketiga, adanya mental yang dominan di mana ide-ide individu sendiri hampir sepenuhnya ditentukan oleh tempat dan tugasnya dalam tertib sosial. ${ }^{3}$ Pada masyarakat yang kompleks atau masyarakat yang lebih modern persoalan HAM justru muncul ketika masyarakat berhadapan dengan negara. Kemungkinan munculnya persoalan HAM pada situasi anomie juga besar. Sebab benturan antara kepentingan masyarakat dan negara seringkali terjadi. Jika benturan ini terus berlangsung maka ketidakpercayaan masyarakat terhadap penguasa negara akan meningkat. Keadaan ini dapat memicu tindakan anarkis yang dapat menciptakan anomie.

Ada persepsi bahwa munculnya persoalan HAM yang ditimbulkan oleh masyarakat dan negara ini karena negara ditempatkan sebagai organisasi kekuasaan. Max Weber mengatakan bahwa negara sebagai organisasi kekuasaan mempunyai hak dan monopoli hukum dan kekuasaan dan berhak melaksanakan berlakunya hukum dan kekuasaannya itu kepada warganya. ${ }^{4}$ Weber juga berpendapat bahwa kepentingankepentingan negara begitu dominan di tengah

2A.A.G. Peters dan Koesriani Siswosoebroto. 1988. Hukum dan Perkembangan sosial. Buku Teks sosiologi Hukum. Jakarta: Sinar Harapan. HIm. 33, 146- 147.

${ }^{3}$ Roberto Mangabeiro Unger. 1976. Law in Modem Society. New York: Free Press Maccmillan Publishing Co. Him. 226.

${ }^{4}$ Arif Budiman. 1997. Teori Negara. Jakarta: Gramedia Pustaka Utama. 
masyarakat sehingga aturan-aturan normatif yang berlaku di masyarakat dipengaruhi oleh berbagai kepentingan yang ada. ${ }^{5}$

\section{Wạcana tentang Hak Asasi Manusia}

Diskursus mengenai HAM pada tulisan ini akan berangkat dari suatu asumsi dari Peters, bahwa realitas sosial modern mempunyai sifat yang belum selesai dan telah dipolitikan. ${ }^{6}$ Sebagai bagian realitas sosial modern, hak asasi manusia merupakan persoalan yang akan terus mewarnai kehidupan manusia, dan dapat dipastikan bahwa isu yang telah menjadi mainstream dalam bentang sejarah perjalanan hidup umat manusia di muka bumi ini adalah isu mengenai Hak Asasi Manusia (HAM). Satjipto Rahardjo mengatakan bahwa HAM sudah menjadi topik sehari-hari yang kemunculannya tidak dapat dibayangkan adanya beberapa puluh tahun yang lalu. ${ }^{7}$ Persoalan HAM meningkat baik dari segi kualitas dan kuantitasnya seiring dengan perkembangan masyarakat. Demikian pula strategi gerakannya. Dalam pengamatan Escobar dan Alvares (1992) persoalan HAM ini telah mendapatkan bentuknya dalam gerakan-gerakan sosial modern (New Social Movement) yang mempunyai kaitan dengan gerakan-gerakan lain dalam proses sosial yang luas, yaitu proses sosial yang mewarnai hubungan masyarakat sipil dan negara. ${ }^{8}$
Isu HAM merupakan isu yang sering dijadikan alat politis bagi berbagai kepentingan golongan yang mengatasnamakan masyarakat manusia maupun kepentingan penguasa suatu negara yang mengatasnamakan Kemanusiaan dan Keadilan. Karena HAM senantiasa ditempatkan sebagai jaringan yang strategis untuk merespon sebuah persoalan yang sedang mencuat ditengah-tengah masyarakat dalam suatu negara tertentu maupun pada masyarakat internasional.

Kasus demi kasus yang sangat sensitif dengan persoalan HAM merupan kasus yang mengandung reaksi dunia internasional. Namun, hal itu seiring digunakan oleh kebanyakan negara yang mempunyai kepentingan baik politik, ekonomi maupun ideologi untuk intervensi dengan cará mempressure baik melalui saluran kebijakan lembaga internasional (misal: PBB) maupun melalui saluran yang berada diluar sistem kelembagaan formal. Issu HAM ini akan semakin meruncing apabila respon atau persoalan yang bersinggung dengan HAM (semacam perburuhan, penggusuran, pemberontakan, pelanggaran hukum, dan lain-lain) tidak didasari oleh pemahaman yang mendalam baik terhadap persoalan yang menjadi basis issu tersebut, maupun terhadap konsep HAM itu sendiri.

Banyak negara yang serta merta menuding suatu negara telah melanggar HAM tanpa

${ }^{5}$ A.A. G. Peters dan Koesriani S, Ibid.

${ }^{6} \mathrm{lbid} . \mathrm{HIm} .18$.

'Satjipto Rahadjo. Hukum Masyarakat dan Pembangunan. Bandung:Alumni, 1980, HIm. 99.

${ }^{8}$ Mansour Fakih. "Gerakan Perempuan dan Proses Demokratisasi di Indonesia." Jurnal Unisia No.34l XIXIII/1997. 
melihat secara objektif bagaimana bisa terjadi sebuah kasus yang dianggap sebagai pelanggaran HAM. Suatu contoh yang paling ekstrim adalah sikap negara-negara barat memukul rata penilaian terhadap negara Islam (negara yang sistem hukumnya adalah hukum Islam) sebagai negara yang paling sering melakukan pelanggaran HAM. Padahal penilaian itu berangkat hanya dari sebuah kasus, misalnya hukuman mati atas pembunuh. Penilaian itupun tidak didasari oleh pemahaman terhadap esensi falsafah hukum Islam itu sendiri dan mereka hanya berdalih mengatasnamakan universalitas HAM. Selain itu, sekarang ini terjadi kecenderungan memasukan kepentingan-kepentingan politik dibalik upaya-upaya pembelaan HAM. Akibatnya sekarang ini tuding menuding tentang pelanggaran HAM menjadi polemik yang tidak dapat dihindarkan.

Sebenarnya jika dibuka lembaran sejarah polemik tentang perspektif HAM sudah terjadi sejak beberapa abad yang lalu. Ada kondisi yang melatarbelakangi timbulnya pemikiran tentang HAM atau dengan kata lain ada kondisi sosiologis yang tidak dapat dihindarkan ketika isu mengenai HAM mencuat kepermukaan. Dalam literatur yang membahas mengenai perkembangan HAM telah dicatat bahwa permulaan gagasan perumusan tentang $H A M$ dalam praktik bernegara baru dimulai pada abad ke-17. Manifestasi pemikiran HAM pada waktu itu dirumuskan dalam undang-undang seperti Bill of Rights di Inggris tahun 1889, Declaration des droits de l' homme et du citoyen di Prancis 1789 dan Bill of Rights of America tahun 1789. Jauh sebelumnya di Inggris ada Piagam pembatasan kekuasaan raja, yang dikenal dengan sebagai Piagam Agung (Magna Charta) tahun 1215. Namun hak-hak yang dirumuskan pada waktu itu lebih banyak mendapat pengaruh dari natural law (hukum alam). Batasan hak pada masa itu terbatas pada hak yang bermuatan politis. ${ }^{9}$ Konsep HAM yang demikian berlangsung hingga abad ke-18. Pada abad ke-18 muncul tesis tentang HAM sebagai hak pemberian Tuhan dan merupakan konsekuensi dari penciptaan manusia. Karena itu HAM merupakan hak kodrat yang dibawa manusia sejak lahir, dimiliki manusia secara alamiah dan dibawa dalam hidup bermasyarakat. Pada abad ini penekanannya pada hak kebebasan. Corak pemikiran pada abad 18 ini lebih rasionalistik sesuai dengan alam pikiran filsafat pada waktu itu yang menonjolkan rasionalisme ilmu pengetahuan dan materialisme. Karena itu konsep HAM yang semula direduksi dari hukum alam kemudian ditransformasi dalam bentuk rumusan yang rasional, invidualistik, liberal, dan universal. Substansi HAM yang ditonjolkan pada abad ke-17 dan abad ke-18 adalah hak kebebasan sipil, (civil libertis rights) dan hak untuk memiliki (rights to have). Kemudian pada abad ke-19 muncul konsep HAM bercorak sosialis. Aliran yang sedikit banyak mendapat metaforse aliran sosialis ialah aliran utilitarian dari Mill dan Speencer. Karena itu, pandangan utilitarian mengenai HAM berpijak pada paradigma bahwa prinsip

${ }^{9}$ Miriam Boedihardjo. 1988. Dasar-dasar IImu Politik. Cet ke XI Jakarta: Gremedia. HIm. 121. 
Hak adalah persamaan hak dalam memberi kebahagian terbesar bagi rakyat banyak. Pemikiran HAM pada masa ini adalah antitesis dari abad sebelumnya. Kemudian pada abad ke-20, muncul pemikiran yang mencoba mensintesakan tesis pada abad ke-17-18 dan anti tesis pada abad ke-19. Sintesis abad ke20 ini mempunyai beberapa peran. Pertama, menjembatani hukum kodrat dan hukum positif. Kedua, mengawinkan HAM yang ditekankan pada hak individu dan kelompok dengan HAM yang ditekankan kesejahteraan sosial dan ekonomi. Ketiga, mempertemukan pandangan yang menganggap pemerintah sebagai ancaman terhadap kebebasan individu dengan 'pandangan yang menganggap pemerintah sebagai alat yang dibutuhkan untuk memajukan kesejahteraan bersama.

Pada abad ke-20 juga terdapat perumusan HAM yang menumental yaitu perumusan yang dikeluarkan oleh F.D. Roosevelt dan Piagam PBB tentang hak-hak asasi manusia. Gagasan Roosevelt tentang 4 (empat) kebebasan manusia dilatar belakangi oleh situasi sosial politik yang terus mewarnai sepanjang perang dunia pertama dan perang dunia kedua. Ketika Roosevelt menyampaikan gagasannya di depan kongres pada bulan Januari 1941, hampir seluruh daratan Eropa sedang dalam kekuasaan kediktatoran Hitler. Di Asia Timur, termasuk Timur Jauh, Jepang menunjukkan agresivitasnya. Perlawanan terhadap kolonialisme dan imperialisme berkobar di mana-mana. Martabat kemanusian seolah tiada harganya di hadapan kekuatan ketika itu. Ribuan bahkan jutaan manusia terhempas menjadi korban peperangan. Kondisi ini menjadi kegelisahan nurani dan intelektual Roosevelt sehingga dengan lantang mengatakan bahwa manusia dimanapun didunia mempunyai kebebasan untuk memilih agama yang diyakininya, kebebasan berbicara dan menyatakan pendapat, bebas dari kekurangan dan kemiskinan dan bebas dari rasa takut. ${ }^{10}$

Abad ke-20 merupakan abad yang diwarnai oleh tarik menarik yang begitu tajam antara konsep liberalisme-individualisme dan konsep sosialisme. Konsep aliran liberal berpegang pada prinsip bahwa individuindividu merupakan subjek utama yang harus mendapat prioritas perlindungan hak asasinya. Pihak sosialisme berpegang pada prinsip bahwa pandangan individualisme telah melahirkan manusia yang asosial, mengabaikan hak-hak komunitas masyarakat. Hak asasi menurut sosialis harus berbasis pada hak-hak masyarakat. Dengan demikian kepentingan ideologis telah ikut bermain dalam percaturan perdebatan tentang HAM. Di sisi lain perbedaan persepsi antara dunia Barat yang menilai HAM itu universal dan dunia Timur yang menilai HAM itu relatif menjadi semacam distorsi yang tidak dapat dihindari.

Ada hal yang lebih esensial dari konsepkonsep HAM yang muncul sepanjang sejarah kehidupan masyarakat manusia baik yang sudah tertuang dalam dokumen formal kenegaraan maupun yang muncul dalam

${ }^{10}$ Muchtar Lubis.(Penyunting). 1994. Demokrasi Klasik dan Modem. Jakarta: Yayasan Obor Indonesia. HIm. 211 - 213. 
sengketa konsepsional antara liberalisme dan sosialisme, atau antara dunia Barat dan dunia Timur. Persoalan yang esensial tersebut adalah fakta sosial yang melatarbelakangi munculnya masaiah HAM kepermukaan.

Dalam literatur-literatur klasik yang berbicara tentang negara pada masa sebelumnya terjadinya negara, ada yang menggambarkan bahwa situasi masyarakatnya adalah homo himini lupus hal itu tampak pada pemikiran Hobbes tentang terjadinya negara. Pada saat negara belum berbentuk ada situasi di mana masing-masing individu belum terintegrasi dari segi kepentingan maupun dari segi eksistensinya ditengah suatu komunitas. Masing-masing individu berjalan sendiri-sendiri dalam memperjuangkan kepentingannya. Berbagai benturan tidak dapat dihindari dan perang melawan sesama merupakan kejadian yang mewarnai perjuangan membela kepentingan masing-masing individu. Dalam kondisi ini, situasi serba tidak beraturan, disharmoni, sangat dominan. Keadaan ini mendorong individu-individu untuk menyatu dalam suatu komunitas masyarakat yang lebih luas. Dalam komunitas tersebut lalu ada kesepakatankesepakatan untuk mengakhiri situasi homo homini lupus dengan membentuk suatu wadah yang nantinya akan mengakomodasi tiap-tiap kepentingan yang ada ditengah komunitas masyarakat. Mereka bersepakat membentuk negara. Inilah yang kemudian disebut oleh Hobbes, Pacta Unionis. Namun apakah setelah terbentuknya negara persoalan menjadi selesai? Ternyata tidak. Sebab ada pekerjaan yang merupakan tindak lanjut dari pacta unionis, yang melakukan kesepakatan untuk mengangkat kepala negara dan kepala negara ini akan mengadakan perjanjian dengan masyarakat yang mengangkatnya yang intinya melindungi hak-hak masyarakat dalam menjalankan kekuasaan negara. Ini disebut oleh Hobbes sebagai pacta subjectionis.

Meskipun negara telah terbentuk lalu seorang pemimpin negara sudah dipilih dan diangkat, ternyata persoalan benturanbenturan kepentingan yang bersubstansi hakhak dan kewajiban-kewajiban tidak dapat dielakan. Jika kita berangkat dari pemikiran Hobbes yang kemudian populer dengan teori kontrak sosial maka benturan yang tadinya bersifat individual pada saat para negara kemudian meningkat menjadi benturan antara masyarakat dan penyelenggara kekuasaan negara. Sebab, pada kenyataannya penguasa negara justru mengingkari kepercayaan masyarakat dengan memonopoli kekuasaan. Penguasa akhirnya menerapkan rezim pemerintah yang otoriter, absolut bahkan diktator. Rakyat yang tadinya mempunyai kedaulatan baik ketika akan membentuk negara maupun ketika akan menentukan pemimpinnya kemudian menjadi pihak yang dikendalikan secara represif oleh penguasa negara. Keadaan ini kemudian mendorong rakyat untuk menuntut ditegakkannya keadilan dan dilindunginya hak-haknya sebagai manusia. Keadaan ini mewarnai perjuangan rakyat Inggris menjelang dicetuskannya Magna Charta dan Bill if Right, kemudian di Prancis yang mendorong kelahiran Piagam Perlindungan Hak-Hak Warga Negara, di Amerika Serikat menjelang Bill of Right Amerika serta di beberapa negara yang kondisi sosialnya mendorong kelahiran dokumen hukum tentang perlindungan HAM.

Tampaknya perbedaan konsepsi senantiasa berjalan mengikuti alur zaman. 
Antara konsep Barat-Timur kini masih terasa. Respon terhadap kondisi ini pun berbedabeda sesuai dengan kultur masing-masing negara. Dalam pandangan Daniel S. Lev, akar dari keanekaragaman budaya yang berkaitan dengan HAM pada umumnya hanya mitosmitos yang mendapatkan bentuknya pada masa imperialisme dan kolonialisme Eropa. Zaman itulah yang melahirkan polarisasi kebudayaan barat dan timur yang saling dipertentangkan. Pola barat diidentikan dengan demokrasi sementara itu pada pola timur diidentikan dengan komonitarian. Kondisi ini sebenarnya menyesatkan." Memang akibat adanya polarisasi ini menimbulkan pro dan kontra. Adapula yang tidak mengambil sikap dan tidak memihak Barat maupun Timur tapi berusaha merumuskan konsep sendiri sesuai dengan kondisi sosiokultur, sistem ideologi dan sistem hukumnya seperti Indonesia.

Pada mulanya di Indonesia sejarah pemikiran HAM sudah mulai diperdebatkan pada waktu sidang BPPUPKI. Pada saat itu, Hatta mengusulkan adanya pencantuman hak warga negara dalam rancangan UUD 1945 namun usul Hatta ditolak Soepomo-Soekamo dengan alasan bahwa hak itu berasal dari pemikiran liberalisme dan individualisme. Meskipun ditolak pada akhirnya UUD 1945 tetap memuat hak-hak warga negara. Rekonsiliasi pandangan Hatta dan SoepomoSoekarno ini menegaskan keberadaan HAM dalam Konstitusi Republik Indonesia sangat mendesak. ${ }^{12}$

Saat ini tampaknya ketegangan yang mewamai perjalanan sejarah pemikiran HAM antara Barat dan Timur sudah mulai meredah. Justru yang menonjol sekarang ini adalah apakah HAM itu universal ataukah relatif. Karena itu munculah universalisme dan relativisme HAM. Universalisme berpandangan bahwa HAM adalah hak dasar yang dimiliki oleh semua manusia diregion manapun mereka berada tetapi tidak dapat dipersamakan sebab masing-masing negara mempunyai ciriciri khas yang berbeda, mempunyai kultur yang berbeda dan mempunyai tantan sosial yang tidak sama.

Tarik menarik antara universalitas yang masih berlangsung sampai sekarang ini sebenarnya masih mempunyai relevansi dengan pandangan suatu negara terhadap persoalan HAM. Menurut Eddy Prasetyo, ada dua perspektif yang terkait dengan pandangan negara terhadap HAM. Pertama, perspektif Autonomy of state yang berprinsip bahwa kedaulatan negara adalah hal yang terpenting. Karena itu, persoalan HAM adalah persoalan domestik suatu negara. Kedua, perspektif cosmopolitan yang berprinsip bahwa negara adalah persoalan yang melampaui batasbatas nasional suatu negara bangsa. ${ }^{13}$ Pandangan autonomy of state dan cosmopolitan ini masih bergulir di tengah mulai menguatnya

"Daniel S. Lev. "Hak azasi Manusia, Perpektif Amerika." Dalam Jumal Analisis CSIS TH. XXII. No. 1Januari-Februari 1993. Him. 394.

${ }^{12}$ Rudini. 1994. Atas Nama Demokrasi Indonesia,. Yogyakarta: Bigraf Publising.

${ }^{13}$ Eddy Prasetyo. "HAM Dalam Hubungan Internasional." dalam Jurnal Analitis CSIS. TH. XXIl. No.1. Januari-Februari 1993.HIm. $77-78$. 
negara dunia ketiga. Walaupun negaranegara dunia ketiga ini sepakat akan menciptakan harmoni hubungan utaraselatan, barat-timur dan negara-negara maju dengan negara-negara berkembang serta negara-negara miskin dengan prinsip saling menghormati, tetapi persoalan HAM tetaplah menjadi agenda politik internasional yang diwarnai oleh sikap arogan negara-negara yang mengklaim sebagai pembela HAM dengan alasan HAM adalah universal. Demikian pula sikap defensif dari negaranegara yang bersikukuh bahwa HAM itu relatif dengan satu alasan bahwa tak satupun negara dapat mengintervensi urusan dalam negeri suatu negara walaupun dengan dalih membela HAM, masih terus memicu timbulnya kontlik, baik konflik tertutup atau sekedar perang urat saraf maupun konflik terbuka yang sampai menimbulkan tindakan destruktif.

Perbedaan konsepsional tentang ini telah membawa implikasi pada implementasi Perlindungan HAM oleh negara. Cara pandang yang berbeda tentang esensial HAM yang telah melahirkan tentang siapa yang bertanggung jawab terhadap pelanggaranpelanggaran HAM tidak hanya terjadi di dalam lingkup negara tertentu tetapi meluas ke kancah internasional yang kemudian mendorong sejumlah negara untuk turut intervensi dalam menyelesaikan persoalanpersoalan yang bersinggungan dengan HAM di suatu negara.

\section{HAM dalam Masyarakat Bernegara}

Hingga kini konsep-konsep HAM yang muncul sepanjang sejarah sebenarnya pararel dengan terjadinya perubahan struktur masyarakat dan tampilnya kelompokkelompok masyarakat. ${ }^{14}$ Selain itu, secara sosiologis, munculnya persoalan HAM di tengah masyarakat selalu bersinggungan dengan wacana negara hukum dan proses demokrasi. Pembahasan tentang HAM pada bagian ini tidak akan terlepas dari konteks tersebut.

Hingga kini implementasi HAM masih diwarnai oleh ketegangan yang disebabkan oleh perbedaan konsep, apakah HAM: meliputi hak-hak sipil dan hak politik serta hak ekonomi secara terpisah atau secara bersama-sama serta apakah HAM itu melekat pada tiap individu atau juga terkait dengan hak masyarakat. Sebenamya ketegangan karena adanya kontroversi mengenai HAM itu telah berlangsung begitu lama adalah merupakan imbas dari tarik menarik orientasi HAM yang telah diwariskan oleh sejarah. Sejarah telah membuktikan bahwa implementasi perlindungan HAM tidak dapat menghindar dari vested intersets.

Sebenarnya dikotomi konsep tersebut tidak perlu dilanggengkan. Sebab secara hakiki HAM itu mempunyai dimensi kosmologis-theologis. Bagi yang yakin akan adanya otoritas Tuhan maka persepsi bahwa HAM adalah pemberian Tuhan yang melekat

${ }^{14}$ Eggy Sudjana dan Ali Sofyan Hussein. 1998. Hak Asasi Manusia dan Pembangunan. Jakarta: CIDES, HIm. 10. 
pada setiap manusia di masyarakat manapun manusia hidup, tidak dapat ditolak. Dengan demikian HAM yang bermuatan nilai-nilai universa! menembus batasan-batasan geografis suatu negara. Lalu mengapa pada akhirnya negara perlu melakukan intervensi terhadap pelaksanaan dan perlindungan HAM? Hal itu tidak terlepas dari konsepsi bahwa negara adalah sebuah sistem yang mempunyai ideologi atau dasar pandangan hidup. Negara adalah sebuah sistem sosial yang diatur oleh hukum dan negara. merupakan sistem sosial yang mempunyai keberagaman kebudayaan. Karenanya, negara berkewajiban menjamin kehidupan yang harmonis bagi warganya yang mempunyai kebudayaan yang heterogen dan negara harus mampu mengakomodir berbagai kepentingan yang terkait langsung dengan hak-haknya baik hak sebagai warga negara maupun hak-haknya sebagai manusia. Karena itu negara tampil sebagai satu-satunya lembaga yang mempunyai otoritas untuk memberi perlindungan HAM bagi warganya atas dasar tanggung jawabnya dalam menciptakan tata kehidupan yang tertib, aman sejahtera bagi warganya. Walaupun HAM adalah sebuah nilai universal, tapi tidak semua negara berada pada kondisi yang sama. Karena itu negara memiliki keharusan secara legal untuk mewujudkan pelaksanaan dan perlindungan HAM secara maksimal.

Warisan sejarah membuktikan bahwa kewenangan negara untuk melindungi HAM baik itu tentang hak kebebasan individu, hakhak sipil maupun hak-hak politik tidak pemah dilandasi oleh keinginan untuk memberi kebebasan individu di luar sistem politik. Kewenangan negara lebih banyak didasari oleh keinginan untuk menciptakan pada perjuangan agar individu-individu dapat berinteraksi dalam membentuk suatu bentuk kehidupan yang menjamin adanya hak-hak asasi manusia. ${ }^{15}$ Dengan demikian sesungguhnya kewenangan negara untuk menjamin pelaksanaan dan perlindungan HAM dilatarbelakangi oleh sejarah perjuangan HAM yang memberi preseden bagi negara untuk senantiasa membawa implementasi HAM dalam kerangka sistem sosial-politik dari negara yang bersangkutan. Oleh karena itu, kewenangan negara untuk mengatur implementasi HAM adalah sejauh dalam sistem sosial dan sistem politik yang telah digariskan.

Ada beberapa pemikiran yang berkaitan dengan perlunya negara mengambil pesan dalam mengatur perlindungan hak asasi manusia bagi warganya. Pertama adalah pemikiran yang berangkat dari perjalanan sejarah negara menjadi sebuah sistem kemasyarakatan yang harus melindungi warganya dan harus memberi jaminan bagi kesejahteraan warganya. Ketika negara bermula dari proses interaksi dalam suatu pergaulan hidup yang melahirkan sebuah komitmen untuk menciptakan keteraturan dan ketertiban serta perdamaian dalam pergaulan hidup maka sejak itu telah lahir ide untuk menciptakan sebuah wadah yang dapat mengakomodasi semua keinginan dan kepentingan warganya. Dalam kajian-kajian

1sEdi Prasetyo. Ibid. 
ilmu negara, terutama yang mengkaji sejarah asal mula negara, hampir semua pemikir ilmu negara menyertakan rakyat sebagai unsur penting bagi pembentukan negara. Bahkan rakyatlah salah satu syarat mutlak adanya negara. Karena dari rakyatlah ide bernegara muncul. Prof. Nasroen mengatakan bahwa negara terjadi karena proses pergaulanpergaulan hidup rakyat yang selalu sadar mempunyai kehendak bernegara. Ide bernegara adalah adanya kemauan rakyat. ${ }^{16}$ Dengan demikian ada proses sosiologis tentang terjadinya negara, di mana ada interaksi antar individu dalam suatu komunitas. Dalam proses interaksi itulah muncul kaidahkaidah yang pada akhirnya menjadi hukum yang harus ditaati bersama. Adapun kewajiban bagi negara ialah memberi perlindungan kepada warganya sebagai konsekuensi logis dari proses terbentuknya negara.

Perlindungan yang diberikan negara terhadap hak asasi manusia para warganya juga dilandasi oleh keharusan negara untuk mengatur hubungan-hubungan lahir antar manusia di dalam masyarakat. Di samping itu, negara juga menopang dan mendayagunakan sistem kemasyarakatan untuk menciptakan tata tertib dan mewujudkan kesejahteraan bagi masyarakat. ${ }^{17}$

Dalam konteks pengaturan hubungan lahir antar manusia ini memang mengesankan adanya peran negara yang besar dalam mengintervensi kehidupan masyarakat. Jika peran negara ini tidak dibatasi oleh peraturanperaturan maka ada kemungkinan terjadi pelanggaran terhadap hak asasi rakyat, karena itu negara harus mencantumkan tata tertib yang berkeadilan dan tidak melibas hak asasi manusia para warganya. Perlindungan negara terhadap HAM juga tidak sekedar menjalankan kewajiban historis dari kelahiran negara melainkan juga melaksanakan tanggung jawab moral untuk memberikan apa yang menjadi hak rakyat setelah mereka melakukan kewajiban terhadap negara. Perlindungan ini juga merupakan realisasi dari tanggung jawab negara yang tidak mengingkari besarnya peran rakyat dalam pembentukan negara.

Kemudian, pemikiran kedua adalah pemikiran yang berangkat dari wacana negara modern yang berpihak pada konsep negara hukum, dan demokrasi. Ada korelasi yang sangat erat antar negara hukum dan sendi-sendi demokrasi. Tegaknya negara hukum dan negara demokrasi inheren dengan tegaknya pelaksanaan perlindungan HAM oleh karena perlindungan HAM adalah faktor yang sangat essensial dan substansial bagi negara hukum yang demokratis.

Hampir semua penggagas konsep negara hukum seperti Friedman, Kant, Stahl dan A.V. Dicey menetapkan perlindungan HAM sebagai substansi yang penting bagi negara hukum. Friedman dan Kant dengan konsep negara sebagai penjaga malam mengkristalkan dua unsur penting bagi negara hukum yaitu perlindungan HAM dan pemisahaan kekuasaan. Kemudian F.J. Stahl dengan konsep Welvaarstaat juga menempatkan unsur jaminan terhadap HAM sebagai salah

:8M. Maroen. 1989. Asal Muasal Negara. Jakarta: Pustaka Tinta Mas. Hlm. 72-81.

${ }^{17}$ Mac. Iver. 1977. Negara Modern, Jakarta: Angkasa Baru. HIm. 13. 
satu unsur penting bagi terwujudnya negara kesejahteraan. A.V. Decey penggagas konsep the rule of law juga menjadikan human right sebagai substansi yang harus ada dalam the rule of law. Hal yang sama juga dilakukan secara kolektif oleh para juris asia tenggara dan pasifik. ${ }^{18}$

Kemudian, dalam perspektif demokrasi, persoalan jaminan HAM juga menjadi perhatian yang sangat serius sebab inti dari pada demokrasi adalah bagaimana hak-hak rakyat termasuk hak asasinya diberikan secara adil dan sesuai dengan asas demokrasi yang berasal dari rakyat, dilakukan oleh rakyat dan sudah semestinya kembali kepada rakyat. Pemberian kesempatan kepada warga negara (rakyat) untuk memperoleh apa yang menjadi haknya adalah syarat bagi negara demokrasi. Diamond, Linz, dan Lipset mengatakan bahwa demokrasi merupakan suatu sistem pemerintahan yang memenuhi tiga syarat. Pertama, adalah adanya hak kompetisi yang riil dan meluas bagi warganya. Kedua, adalah hak berpartisipasi dalam politik yang dapat melibatkan sebanyak mungkin warga negara serta adanya hak kebebasan politik dan kebebasan sipil yang akan menjamin hak berkompetisi dan berpartisipasi dalam politik. ${ }^{19}$

Keberadaan warga negara dalam dinamika negara demokrasi membawa implikasi terhadap kewajiban negara untuk melindungi warganya dalam menyelenggarakan hak dan kewajibannya di hadapan hukum dan pemerintahan. ${ }^{20}$ Oleh karena itu, pemberian perlindungan HAM dalam konteks demokrasi sepatutnya tidak hanya terfokus pada pemberian hak kebebasan sipil dan hak kebebasan politik namun harus mencakup wilayah yang lebih luas seperti pemberian keleluasaan keterlibatan rakyat dalam menentukan kehidupan bersama, hak untuk mendapat perlakuan yang wajar di depan hukum (equality before the (aw) dan pemberian hak-hak sosial ekonomi secara manusiawi.

Perlindungan HAM oleh negara dalam konsep demokrasi mengandung dua dimensi. Pertama adalah dimensi negatif di mana hak untuk melindungi seseorang dari tindakan yang merugikan dan intervensi pemerintah negara dalam hal hak-hak sipil dan politik adalah sesuatu yang sangat penting. Dimensi kedua adalah dimensi positif di mana negara melakukan perlindungan hak sipil dan hak politik rakyat dan konskuensinya dari itu mengharuskan negara memberikan hak-hak sosial ekonomi bagi warga negaranya melalui peraturan atau lembaga peradilan. ${ }^{21}$ Negara memang harus proaktif dalam mengindentifikasikan persoalan HAM yang muncul ke permukaan akibat disintegrasi dan konflik-konflik yang ada di tengah masyarakat serta akibat dari kekuasaan yang represif. Selanjutnya negara perlu

${ }^{18 D i d i ~ N a z m i ~ Y u n u s . ~ 1992 . ~ K o n s e p ~ N e g a r a ~ H u k u m . ~ J a k a r t a: ~ P e n e r b i t A n g k a s a ~ R a y a . ~ H I m . ~ 24-25 . ~}$

${ }^{19}$ Muchtar Mas'oed. 1994. Negara Kapital Dan Demokrasi. Yogyakarta: Bintang Pelajar. HIm. 11.

${ }^{20}$ Ramly Hutabarat. 1985. Persamaan di Hadapan Hukum di Indonsia. Jakarta: Penerbit Ghalia Indonesia. HIm. 24-25.

${ }^{2}$ MT. Arifin. "Tantangan Politik HAM." dalam Harian Suara Merdeka. Selasa 23 Maret 1997. 
mengantisipasinya dengan mewujudkan perlindungannya melalui mekanisme kelembagaan. Menurut Miriam Budiardjo, dalam konsep politik, negara mempunyai dua tugas. Tugas pertama ialah mengatur gejalagejala kekuasaan yang asosial, yakni bertentangan satu sama lain sehingga tidak terjadi antagonisme. Tugas kedua iàlah mengorganisir dan mengintegrasikan manusia dan golongan-golongan ke arah tercapainya tujuan-tujuan yang ingin dicapai oleh masyarakat negara juga menentukan kegiatan asosiasi-asosiasi kemasyarakatan yang disesuaikan dengan tujuan nasional. ${ }^{22}$

Demikian dua dasar pemikiran yang merupakan dua awal dari keberangkatan negara untuk memberikan perlindungan yang maksimal tèrhadap hak asasi para warganya. Sekarang persoalannya adalah bagaimana negara melakukan upaya konkrit terhadap urgensifnya perlindungan terhadap HAM? Di sini ada dua cara yang dapat ditempuh penguasa negara. Pertama melalui hukum konstitusi dan peraturan perundang-undangan organiknya. Kedua, melalui mekanisme pelembagaan perlindungan HAM. Masyhur Effendi mengatakan bahwa HAM pada tahap pelaksanaanya masuk menjadi persoalan hukum dan harus diatur melalui hukum. Oleh karena itu, landasan hukum yang memuat perlindungan HAM harus tetap dijaga oleh penyelenggara negara. ${ }^{23}$ Perlunya hukum dikedepankan dalam perlindungan HAM karena hukum harus melindungi suàtu struktur kelompok yang vital. Oleh karena itu, akomodasi perlindungan HAM dalam hukum konstitusi sangat penting.

J.G. Steenbeek mengatakan bahwa salah satu ciri yang harus di dalam konstitusi adalah adanya jaminan terhadap hak asasi manusia dan warga negara. Demikian pula C.F. Strong menyatakan bahwa salah satu masalah yang perlu diatur dalam konstitusi adalah Hak Asaśi Manusia. ${ }^{24}$ Pemikiran ini tidak terlepas dari posisi persoalan HAM yang menjadi bagian realitas sosial, terlebih dalam masyarakat modern. Dalam posisi ini HAM menjadikan fakta yang akan terus bergulir secara intens. Karena itu, hukum harus mampu memberi kerangka normatif bagi fakta-fakta atau gejalagejala sosial.

Konstitusi merupakan hukum dasar yang mengatur hal-hal fundamental dalam kehidupan bernegara. Konstitusi lahir atas desakan gerakan rakyat yang berdaulat yang memiliki kesadaran akan perlunya landasan hukum untuk membatasi kekuasaan dan mencegah terjadinya kesewenang-wenangan penguasa negara dalam melaksanakan jaminan perlindungan terhadap hak-hak asasi rakyat. Dengan demikian hukum konstitusi muncul atas desakan reaksi sosial rakyat yang menuntut tindakan yang tegas terhadap upaya penyelewengan dari perlindungan tèrsebut. Dengan kata lain, konstitusi memberi dasar tindakan konstitusional bägi warga negara

${ }_{2}^{2}$ Miriam Budihardjo.Op.Cit. HIm. 39.

${ }^{23}$ /bid.

${ }^{24}$ Sri Soemantri. "Fungsi Konstitusi dalam Pembatasan Kekuasaan." Dalam Jumal Hukum. No.6 Vol. 3 1996. HIm. 3. 
berkaitan dengan komitmen penguasa negara untuk melindungi warga negaranya beserta hak-hak asasinya.

. Qalam kajian hukum modern, HAM yang diberikan keberadaannya melalui pasal konstitusi dan melalui beberapa pasal dalam perundang-undangan yang secara hirarkhis lebih rendah dari konstitusi adalah hak-hak positif, sebab hak-hak tersebut telah dirumuskan secara tegas dalam produk legislatif. ${ }^{25} \mathrm{Hal}$ ini mempunyai makna bahwa pemberian perlindungan HAM oleh negara melalui konstitusi dan peraturan perundangundangan yang disebut oleh badan legislatif menjadi sangat penting dan merupakan transparansi komitmen negara untuk melindungi warganya. Dengan demikian, pelembagaan perlindungan HAM secara konstitusional selain didasari oleh kebutuhan akan kepastian hukum bagi rakyat juga merupakan konsekuensi dari syarat substansi konstitusi sebagai hukum dasar yang harus memuat masalah prinsipil dalam penyelenggaraan negara.

Konstitusi sebagai dasar hukum tertinggi bagi semua warga negara baik yang duduk sebagai pejabat negara, penegak hukum maupun rakyat biasanya memerlukan komitmen semua warga negara untuk mentaati dan melaksanakan apa yang digariskan konstitusi. Konstitusi adalah hukum dasar bagi negara. Jika hukum dasar bagi negara dilanggar, maka dengan sendirinya negara menjadi rusak. Konstitusi juga tidak menginginkan adanya monopoli dalam kehidupan bernegara terutama dalam kehidupan berpolitik. ${ }^{26}$

Kemudian, bentuk perlindungan kedua adalah melalui mekanisme perlembagaan yang ada dalam struktur kehidupan negara, baik lembaga yudisial maupun lembaga non yudisial. Pelaksanaan penegakan HAM yang intern dengan tugas yang harus dipikul oleh lembaga-lembaga suprastruktur politik, mempunyai legitimasi yang kuat untuk mengambil tindakan-tindakan yang perlu bagi upaya penegakan HAM baik tindakan preventif maupun represif. Tindakan preventif dapat dilakukan melalui peraturan hukum (produk legislatif), sedangkan tindakan represif melalui penegakan hukum yang berpihak pada kebenaran dan keadilan. Adanya legitimasi tersebut belum tentu menjamin bagi tegaknya keadilan dalam implementasi perlindungan HAM. Bahkan, boleh jadi ada kemungkinan tindakan refresif yang berlebihan sehingga bukan perlindungan yang terjadi, namun justru pelanggaran dan penindasan terhadap martabat kemanusiaan. Oleh karenanya, tindakan-tindakan preventif dan represif dari lembaga suprastruktur harus diimbangi dengan kontrol dari lembaga infrastruktur. Para tokoh-tokoh yang kritis, organisasi-organisasi masyarakat, kelompok-kelompok penekan (preassure group) harus diberi ruang untuk mengkritis setiap tindakan lembaga-lembaga negara dalam menjalankan amanat rakyat.

${ }^{25}$ Soètandyo Wignyosoebroto. "Permasalahan Kewarganegaraan di Tinjau dari Prospektif Hak-hakAzasi Manusia." Makalah Seminar Hukum Kewarganegaraan di Fakultas Hukum Universitas Surabaya. 20 September 1997. HIm. 1.

${ }^{26}$ Nurcholis Madjid. "Peneguhan Kesadaran HAM di Indonesia." Dalam Harian Republika, 30 April 1997. 
Bahkan lembaga-lembaga tersebut harus diberi kesempatan yang luas untuk melakukan advokasi bagi terjadinya pelanggaran HAM.

\section{Simpulan}

Penegakan HAM senantiasa melibatkan negara melalui penguasa negara sehingga hal itu memberi ruang intervensi negara. Pemerintah sebagai representasi negara dapat melakukan intervensi sejauh hal itu dapat mencegah terjadinya benturan kepentingan rakyat dan pemerintah. Jika benturan kepentingan ini dapat dihindarkan maka keberadaan lembaga yang netral mutlak diperlukan. Lembaga tersebut dapat berperan sebagai lembaga ketiga yang kehadirannya harus didasari pengertian bersama. ${ }^{27}$

Di Indonesia lembaga khusus yang diharapkan dapat menjembatani kemungkinan terjadinya benturan kepentingan rakyat dan pemerintah adalah Komisi Nasional Hak Asasi Manusia (Komnas HAM). Meskipun kehadiran Komnas ini dibidani oleh presiden namun kedudukan Presiden harus dilihat sebagai kepala negara yang telah mendapatkan mandat dari rakyat melalui MPR untuk melaksanakan tugas-tugas kenegaraan. Ketika Komnas ini lahir melalui Kepres №. 15 tahun 1990, banyak orang skeptis lantaran Komnas ini dibentuk oleh Presiden yang nota bene sebagai eksekutif sehingga akan membuka peluang adanya penetrasi dari executive power dalam menjalankan tugas-tugas yang diemban oleh Komnas HAM. Namun setelah Komnas ini berjalan dan telah membuktikan kemandiriannya, maka banyak orang mengarahkan perhatian terhadap keberadaannya. Bahkan reaksi masyarakat begitu antusias sehingga seolah-olah lembaga ini "Dewa Penolong" bagi rakyat yang merasa dirugikan hak-hak asasinya bahkan ada fenomena di masyarakat yang menganggap bahwa Komnas HAM bisa menggantikan lembaga peradilan dalam penegakan terhadap hak-hak asasi manusia. Padahal, Komnas HAM hanya memberi rekomendasi kepada lembaga-lembaga peradilan dan lembaga-lembaga politik dari hasil penyelidiknya atas fenomena-fenomèna pelanggaran HAM.

Fenomena bahwa Komnas HAM dapat menjalankan fungsi peradilan perlu diluruskan. Sebab keberadaan Komnas HAM dan lembaga peradilan berada dalam struktur yang berbeda. Komnas HAM adalah lembaga yang dibentuk secara khusus berdasar kebijakan kepala negara. Sedangkan lembaga peradilan menjadi bagian yang tidak dapat dipisahkan dari sistem negara hukum. Memang kebanyakan masyarakat yang lari dari Komnas HAM karena mereka kurang bahkan tidak puas dengan penyelesaian yang selama ini dilakukan oleh lembaga peradilan. Namun agar salah persepsi ini tidak terus meluas maka harus ada publikasi secara transparan mengenai tugas Komnas HAM kepada masyarakat luas.

Pada akhirnya negara memang harus melembagakan perlindungan akan hak-hak

${ }^{27}$ Novel Ali. Membubarkan Komnas HAM Merusak Citra Bangsa. Dalam Harian Suara Pembaharuan. Senin 8 September 1997. 
asasi bagi warganya. Oleh karena itu negara dapat melakukan intervensi pada kehidupan warganya, tetapi intervensi ini seharusnya tidak sampai kepada hak yang sangat pribadi. Negara cukup mewadahi adanya jaminan terhadap pelaksanaan dan perlindungan HAM melalui peraturan perundang-undangan dan memaksimalkan peran lembaga-lembaga Peradilan di Indonesia serta merealisasikan rekomendasi-rekomendasi Komnas HAM.

Pada dasamya masalah HakAzasi Manusia merupakan masalah yang kehadirannya mengiringi perubahan-perubahan masyarakat. la menjadi persoalan yang tidak terpisahkan dari realitas sosial yang terus akan berkembang. Dalam perkembangannya ia akan selalu bersentuhan dengan persoalan politik. Tetapi yang terpenting adalah bahwa sebagai bagian dari realitas sosial HAM dalam masyarakat bernegara harus dibingkai dengan hukum yang akan memberinya jaminan, bukan saja jaminan kepastian peraturan di mana HAM diatur dan hanya menekankan dimensi formalprosedural tetapi jaminan kepastian hukum yang akan melandasi realisasi perlindungan dengan berprinsip pada moralitas dan keadilan sebagai materi penting dalam hukum. Peranan negara untuk melembagakan perlindungan HAM para warganya sangat diperlukan karena negara sendiri terbentuk atas dukungan rakyat yang menjadi warga negara setelah negara menjadi kesatuan sistem kemasyarakatan yang mempunyai kewenangan untuk melembagakan perlindungan HAM. Namun demikian kewenangan itu seharusnya tidak menyempitkan arti dan makna hakiki Hak Asasi Manusia yang secara kodrati melekat pada setiap manusia sebagai hamba Tuhan. Selain itu, dalam masyarakat bernegara, tugas menegakkan perlindungan HAM harus dilandasi oleh hukum yang bersendikan moral dan keadilan. Tanpa menafikkan faktor politik, seharusnya upaya penegakan atas terjadinya pelanggaran HAM harus berada pada koridor penegakkan supremasi hukum, bukan supremasi politik, sebab supremasi politik acap kali terkontaminasi dengan kepentingan terselubung.

\section{Daftar Pustaka}

Ali, Achmad. 1978. Menjelajah Kajian Empiris Terhadap Hukum. Jakarta: Yarsif Watampone.

Ali, Novel. Membubarkan Komnas HAM Merusak Citra Bangsa. Dalam Harian Suara Pembaharuan. Senin 8 September 1997.

Boedihardjo, Miriam. 1988. Dasar-dasar IImu Politik. Cet ke XI Jakarta: Gremedia.

Budiman, Arif. 1997. Teori Negara. Jakarta: Gramedia Pustaka Utama

Fakih, Mansour. "Gerakan Perempuan dan Proses Demokratisasi di Indonesia." Jurnal Unisia №:34/XIXIII/ 1997

Hutabarat, Ramly. 1985. Persamaan di Hadapan Hukum di Indonsia. Jakarta: Penerbit Ghalia Indonesia.

Iver, Mac.. 1977. Negara Modern..Jakarta: Angkasa Baru.

Lev, Daniel S.. "Hak azasi Manusia, Perpektif Amerika." Dalam Jurnal Analisis CSIS TH. XXII. No. 1Januari-Februari 1993.

Lubis, Muchtar. (Penyunting). 1994. Demograsi Klasik dan Modern. Jakarta: Yayasan Obor Indonesia. 
Madjid, Nurcholis. "Peneguhan Kesadaran HAM di Indonesia." Dalam Harian Republika. 30 April 1997.

Maroen, M. 1989. Asal Muasal Negara. Jakarta: Pustaka Tinta Mas.

Mas'oed, Muchtar. 1994. Negara Kapital dan Demokrasi. Yogyakarta: Pustaka Pelajar.

MT. Arifin. "Tantangan Politik HAM." dalam Harian Suara Merdeka. Selasa 23 Maret 1997.

Peters, A.A.G. dan Koesriani Siswosoebroto. 1988. Hukum dan Perkembangan sosial. Buku Teks sosiologi Hukum. Jakarta: Sinar Harapan.

Prasetyo, Eddy. "HAM Dalam Hubungan Internasional." dalam Jurnal Analistis CSIS. TH. XXII. No.1. Januari-Februari 1993.

Rahadjo, Satjipto. 1980. Hukum Masyarakat dan Pembangunan. Bandung: Alumni.
Rudini. 1994. Atas Nama Demokrasi Indonesia, Yogyakarta: Bigraf Publising. Soemantri, Sri. "Fungsi Konstitusi Dalam Pembatasan Kekuasaan." Dalam Jurnal Hukum. No. 6 Vol. 31996.

Sudjana, Eggy dan Ali Sofyan Hussein. 1998. Hak Asasi Manusia dan Pembangunan. Jakarta: CIDES.

Unger, Roberto Mangabeiro. 1976. Law in Modern Society. New York: Free Press Maccmillan Publishing Co.

Wignyosoebroto, Soetandyo. "Permasalahan Kewarganegaraan di Tinjau Dari Prospektif Hak-hak Azasi Manusia." Makalah Seminar Hukum Kewarganegaraan di Fakultas Hukum Universitas Surabaya. 20 September 1997.

Yunus, Didi Nazmi. 1992. Konsep Negara Hukum. Jakarta: Penerbit Angkasa Raya. 